\title{
A Proposed National Model of Vocational Education and Training for Micro and Small Enterprises in Kenya
}

\author{
Susan Ngure \\ Department of Business Administration, Dedan Kimathi University of Technology, Nyeri, Kenya \\ Email address \\ sngure37@gmail.com
}

To cite this article:

Susan Ngure. A Proposed National Model of Vocational Education and Training for Micro and Small Enterprises in Kenya. International Journal of Vocational Education and Training Research. Vol. 4, No. 1, 2018, pp. 28-40. doi: 10.11648/j.ijvetr.20180401.15

Received: January 30, 2018; Accepted: March 10, 2018; Published: June 28, 2018

\begin{abstract}
Vocational education and training (VET) in Kenya has undergone major changes since colonialists introduced it at the beginning of the twentieth century. Since then, VET has evolved in the areas of science, technology and innovation to provide more skills, which are expected to serve the needs of the labour market and propel the country to middle-level industrialised status by the year 2030. However, current training and development (T\&D) processes in Kenya have been criticised for being rigid and irrelevant to the industry, creating a mismatch of skills produced by the training institutions and those demanded by the industry; it is upon this criticism that this research is built. The focus of this paper is the development of a more responsive and relevant T\&D model for the VET sector. In Kenya VET is referred to as technical, industrial, vocational education and training - TIVET. To develop a national T\&D model, this paper examined a generic organisational T\&D model. Then, through an examination of literature dealing with VET sub-systems in Kenya and elsewhere, the organisational T\&D was expanded to include relevant national training areas and activities. The requisite areas were identified from reports, academic papers and a combination of both.
\end{abstract}

Keywords: Kenya, Training and Development Models, Vocational Education and Training

\section{Introduction}

This study sought to examine Kenya's Training and Development (T\&D) systems in the Vocational, Education and Training (VET) program. It was occasioned by a call from the Kenyan government for researchers to carry out empirical studies that would provide direction to skills acquisition. Key stakeholders in Kenya have judged that the skills that are produced are inappropriate to the labour industry, that the T\&D was inflexible and that there are poor-quality assurance and monitoring systems [25, 39, 57]. Further, assertions made have highlighted the poor participation of the industry in program. The aim of this research therefore is to develop a T\&D model for the VET program in Kenya. This is done by examining the contribution of VET to developing job-related skills and competencies in micro and small enterprises (MSE). To investigate this topic, data pertaining to T\&DNA, training activities and training evaluation has been sought, analysed, and used to propose a more responsive training and development model.

Vocational Education and training (VET) can be broadly interpreted as the development of ways of learning and the acquisition of attitudes that facilitate success at the workplace [44]. The aim of VET is to contribute to equity and access to training, and social responsibility by stimulating competitiveness and entrepreneurship to realise life-long learning concepts [41] VET plays an important role in supplying skills requisite for improved workers' productivity, economic competitiveness, occupational integration, raising income levels and expanding opportunities for employment $[11,15]$. In addition, formal education and work experience in the formal business sectors enables employers and business owners to improve methods of production, enhance product quality, convey quality information to the users, identify markets, and manage human and other resources, all of which offer students a competitive edge [54].

In the Kenyan context, VET is often referred to as Technical, Industrial, Vocational, Entrepreneurship Training (TIVET), which [6] identified as “... education which is mainly to lead participants to acquire the practical skills, know-how and understanding, necessary for employment in a particular occupation, trade or group of occupations". Factors 
such as active or passive structural adjustment programs, the extensive use of new and modern technological and scientific processes, international competitiveness, flexible labour markets, societal equity and elimination of workplace discrimination [20] have necessitated higher-order thinking skills amongst workers in modern sector businesses and Micro and Small Enterprises (MSE).

TIVET incorporates technical training institutions, youth polytechnics (YPs), MSE training and demonstration centres, and national youth service skills development centres [48]. TIVET programs are offered in YP technical training institutes (TTIs), institutes of technology (ITs), national polytechnics (NP) and numerous other institutions spread across government ministries, as well as private training institutions [47]. At the end of the training period, TIVET graduates acquire certificates or diplomas in various disciplines, while university graduates from the Kenya and Mombasa polytechnic universities are awarded technical degrees.

\subsection{A Kenyan Situational Analysis}

To develop the nation's social and economic advancement, TIVET is expected to play two critical functions: firstly, to offer training prospects and occupation growth for school graduates and, secondly, to provide experienced labour for all levels of the country's economy [23, 25-26]. Due to scarce opportunities in paid employment, the skills developed are expected to lead to self-sufficiency and to advance Kenya's industrialisation processes [57]. This can be achieved through identifying national TIVET policies, developing appropriate programmes, providing sufficient funds, and increasing positive social outlooks for training and improved management-all of which are crucial for successful implementation of the TIVET strategy [48].

TIVET is offered at five levels, which are exemplified in Figure 1 below. Each of these levels has an exit point, where participants can choose to enter the job market or continue to the higher level [25]. At the lowest level of training - the youth polytechnic (YP)-graduates acquire an artisan certificate, which gives them the general knowledge to practise their skills. The second level involves training at technical training institutes (TTIs) and institutes of technology (ITs) to acquire a craft certificate, which involves more theoretical knowledge than the artisan certificate. The third level trains technicians at the national polytechnics (NPs) and a few specific TTIs and ITs, while the fourth level trains technologists at the NPs and universities, who upon graduation may either exit the system or continue to the fifth level for advanced technologists, which is equivalent to a masters level in the Kenyan regular education system.

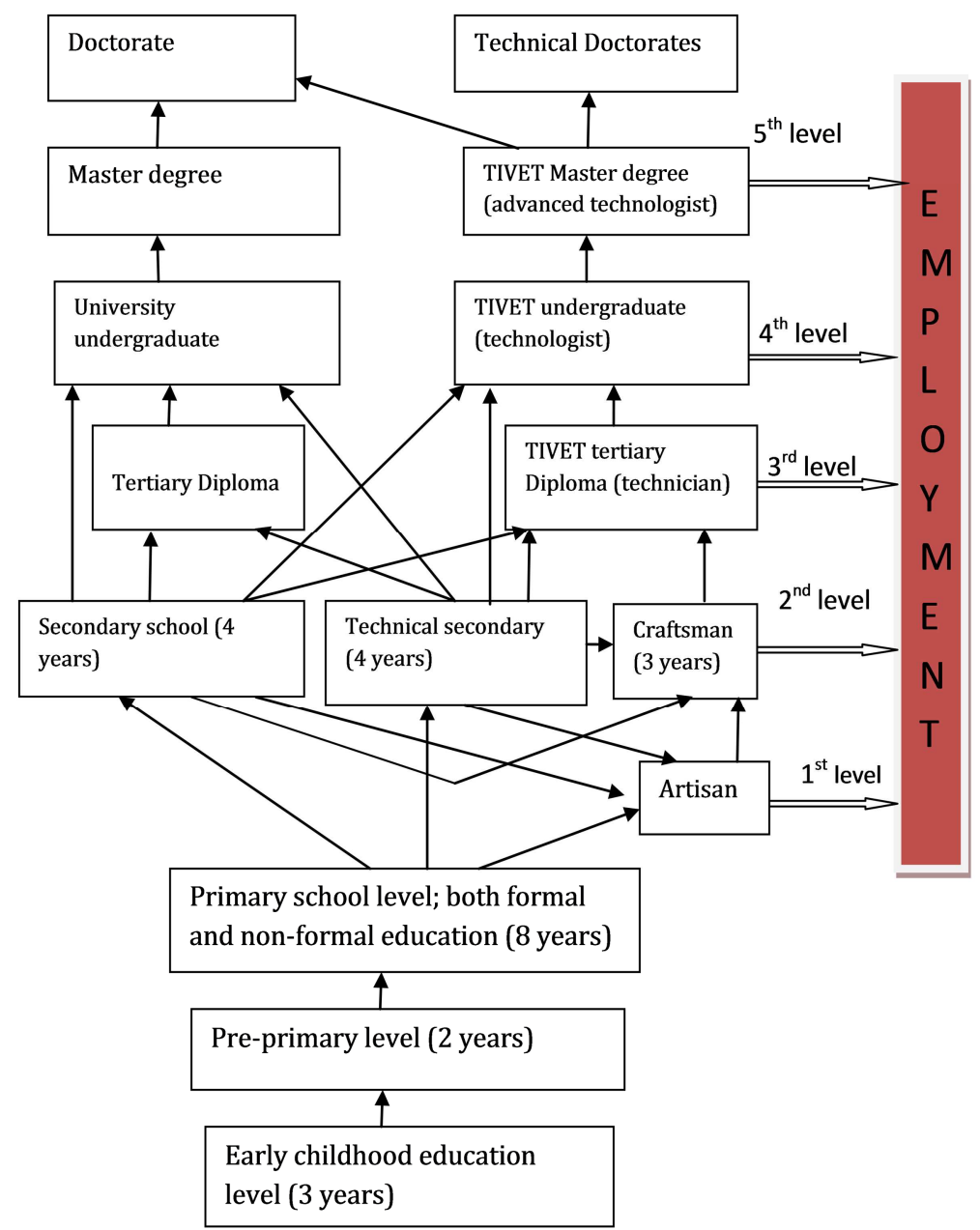

Figure 1. TIVET in Kenya. 
TIVET faces numerous challenges, such as the push for structural adjustment, a rapid increase in population, growing unemployment amongst the youth, the high cost of education against stagnating resources, rural-urban migration, rising social and economic insecurity, reduction in jobs due to economic liberalisation and new technologies, as well as the people's clamour for accountability [9]. In addition, the impact of HIV/AIDS in Africa necessitates an emphasis on skills development to replace those lost across different occupations as the virus drains scarce and productive human resources [48]. These challenges affect the quality, relevance and accessibility of skills and the TIVET program lacks the capacity to respond to them in a timely manner.

Skills development in Kenya is important for economic development, poverty mitigation, and social inclusion. However, the important role that TIVET plays in addressing labour challenges is not spelt out in most policy documents [48]. Kenya's failure to fully embrace the role of TIVET is particularly baffling because most African governments and donor countries are consistent in emphasising the need for intensive structures that shape the human capital of the marginalised. [11] observed that since the late 1980s most African governments have accorded limited significance to donor financing systems and dialogues, aggregating the poor inclusion of VET to the mainstream education systems.

Problems associated with VET in Kenya were amplified by [20] who asserted that most national training systems are supply-driven because providers find it difficult to match institutional course skills with those required at work. In addition, learning institutions in Africa lack mechanisms for counselling potential trainees on career choices, preferring to base their selection on passes of relevant subjects and ignoring the students' interests, expectations and aspirations [31]. The reasons for this are partly due to a lack of information on labour trends and partly due to a lack of funds to carry out a comprehensive assessment of training needs, resulting in graduates' inability to meet employment challenges.

The Kenyan government has well-articulated training objectives that the curriculum was expected to realise, but the government lacked the capacity to do so because some institutions were using very old curricula while others were using foreign curricula that were in conflict with identified Kenyan concepts [49, 32]. A domestic curriculum would check problems associated with foreign curricula-for instance, cultural identities differ in how they conceptualise ideas, in their attitudes and dispositions, verbal and nonverbal reasoning and their perceptions [44].

\subsection{Small Business Sector}

The focus of this study is on MSE skill development through TIVET. In Kenya, MSEs usually employ less than 20 workers. Specifically, micro enterprises employ between 0-5 workers, whereas small businesses have 6-20 workers. The MSE sector is very vibrant in Kenya, which, according to the 2009 census, employs 8.2 million of the workforce, compared to only 2.8 million in the formal sector [28]. Out of the 8.2 million, 6.1 (75\%) are employed in the jua kali sector, which is characterised by strong social relationships and associations [35] but operates under difficult conditions, such as of poor sanitary facilities, ramshackle structures, poor waste disposal and a lack of water and electricity. Despite the sector's large contribution to labour dynamics, MSEs' employment capacity has faced challenges in the form of poor infrastructure, high cost of production and credit, increased competition from cheap imports, and inadequate tools and equipment.

MES's in Kenya are greatly involved in skills transfer. It has been widely acknowledged that more trainees are engaged in informal sector training than in all formal VET institutions in Kenya - for example, [7] put the figure at 71 per cent. Informal training involves learning through observing and doing, and it allows the transmission of the prevailing skills and practices with or without minimal, external resources [57]. With this kind of skill transfer the instructor's ability to offer training is confined to his current skill levels and knowledge, which often results in low productivity [66] Thus, most learning in Kenya occurs at the workplace through the tutelage of MSE managers or supervisors, and non-experts such as colleagues or clients [34]. Authors who advocate informal training, such as [7], cite its advantages of low cost and short training duration; however, it can result in lack of theoretical knowledge, the transmission of bad practices from the trainer to the trainee and restricted pedagogy. [57,63] proposes the integration of institutionalised (formal) and non-institutionalised (informal) education into a coherent system where they supplement each other to resolve the challenges that informal learning faces.

\subsection{Organisational Training and Development Model}

To develop their workforce, organisations make use of a systematic organisational T\&D model to guide training programs. According to $[59,17]$ the three phases of an organisational T\&D model, are sufficient for use by different organisations. This study proposes that the organisational $T \& D$ can form a structure that can be expanded to a national level by including components pertinent to that particular nation. Thus, each phase of the organisational model will be customised to reflect Kenya's TIVET issues and therefore come up with a more responsive T\&D model.

An organisational T\&D model is a prerequisite for developing programs and includes the following three phases: understanding training and development needs assessment (T\&DNA), which comprises a training needs analysis (TNA) and training objectives; establishing the training activities; and evaluating the training $[4,16,55]$. The T\&DNA phase provides direction and purpose for the training effort by seeking to determine what is needed, by whom, when and where, leading to objective formulation; in the activities phase, training methods and learning principles are selected and used; whereas the evaluation phase measures how well the activity met identified objectives [54, 17]. Figure 2 is a diagrammatic representation of the training and development model. 


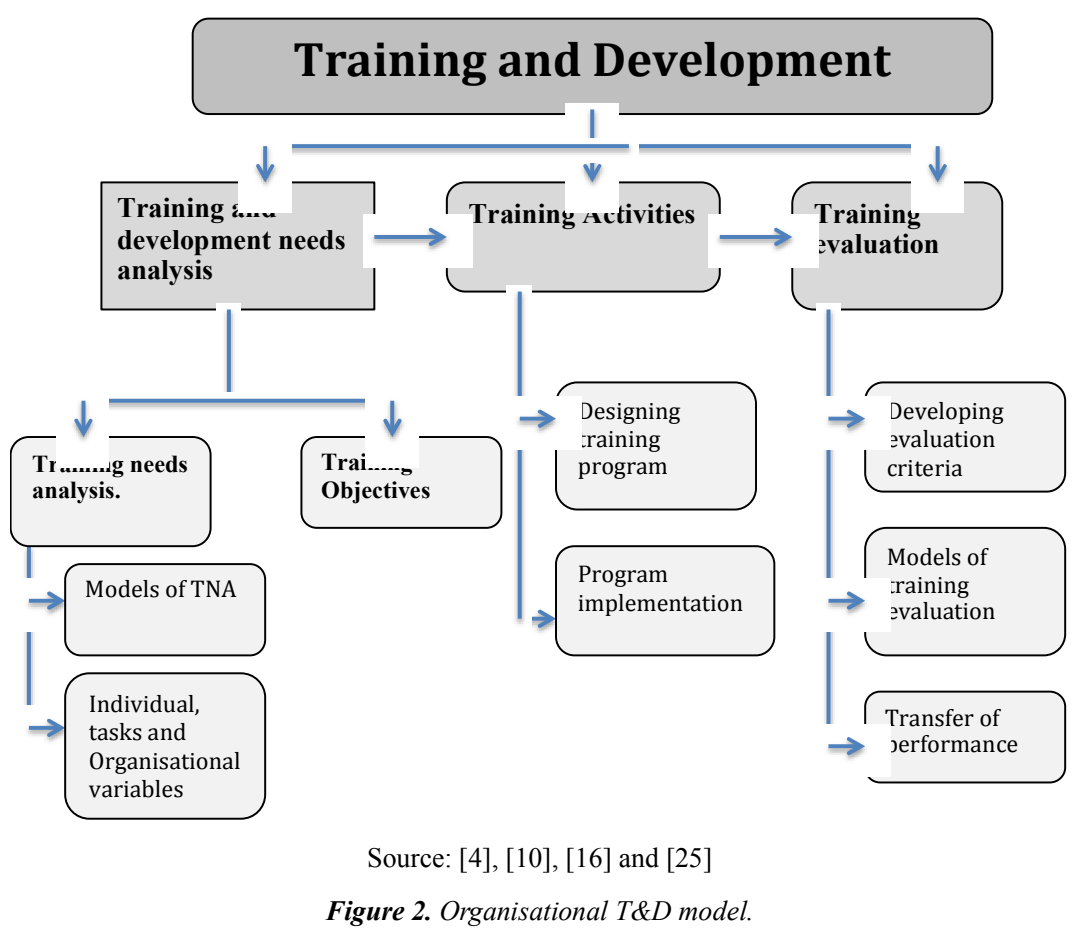

Although the three phases of an organisational T\&D model can be used in a wide variety of programs at the organisation and national level, there is a need to adopt elements that are important for a particular program. For example, VET objectives in the African context differ substantially from those of the developed world. [43] notes that while the developed world, view VET in the light of competitiveness and inclusion, African governments' interest lies in solving unemployment and poverty through the training program. In addition, factors such as financing VET programs, trainer shortages and poor perceptions of the training program call for innovative ways to make the training more attractive to the wider society [7, 34]). Moreover, ways of integrating informal learning and, which trains most of the workers, and the formal learning which has a structure ought to be put in place [38, 7, 57]. In this study the three phases of an organisational T\&D model will be expanded through adding elements that are important for the development of an effective model for TIVET in Kenya.

\section{Justification of the Research}

Kenya government policy documents such Kenya Educational Support Sector Programme (KESSP) [25] Kenya Vision 2030, highlighted the issues and constraints faced by this sector.

1. inflexible and outdated VET curriculum

2. mismatch between the skills learned and the skills demanded by industries

3. inadequate mechanism for quality assurance

4. inadequate physical facilities for training, coupled with lack of sufficient modern equipment

5. expensive training materials and textbooks
6. low participation of private sector in curriculum design and development. [25].

The dearth in empirical data in the TIVET sector drives this study. Furthermore, the numerous challenges that TIVET faces can be addressed by a more responsive and structured training and development. The above cited problems are not only found in the VET context but also in other areas of studies. [56] in a studied educational system and job market in international business law and concluded that the trainings did not match employer's prospects: The authors developed a model of specialization to solve the problems found in this area of study. This study aims to follow these authors and others who have made attempts to improve trainings.

\section{Methodology}

This research paper was a product of vigorous research in the area of VET both in Kenya and around the world. The researcher perused a large amount of literature from all over the world and then compared the practices therein and those within the country to come up with a proposed model of training for the MSE sector in Kenya. The research was occasioned by numerous comments and assertions that the TIVET in Kenya has not been responsive to the industry's needs.

\section{Towards a National Model}

According to the literature gathered from the Government of Kenya $[25,57]$ points to the fact that TIVET in Kenya has not been fully effective, is out-dated and prone to discrepancies between the skills imparted and market needs. Thus, there is a need to develop a T\&D model that would 
address the weaknesses identified by these publications and many others.

To comprehend the issues that are pertinent in the TIVET sector, literature gathered have been grouped in line with the three phases of the organisational training and development model and presented in the following section.

\subsection{Assessing Training Needs and Designing Training Programs}

Government and research papers such as, [24, 25, 28, 26, $37,58]$ revealed that in Kenya there is a discrepancy between the skills offered through TIVET and the needs of the industry. Most literature blamed the poor identification of requisite skills and unsuitable methods of curriculum implementation for the failure of the program to respond to the needs of the industry. To examine how an effective TNA can assist in correctly identifying a training program's needs, this research paper has proposed to divide the TNA processes into four thematic areas, which are discussed below. The four areas have been identified through the examination of publications both in Kenya and the global arena.

\subsubsection{Training Needs Analysis}

This study examined different TNA models and found one that was proposed by Ridha in 1998 to be most ideal for TIVET in Kenya. The model suggested six areas (training programs and contents, training priorities, assumptions behind the choices and priorities, resources required, timing of implementation, and the expected rate of progress and returns). These six areas were used to identify four thematic areas for this study, which are discussed in the following section.

Training programs, content and priorities: The efficacy of a specific instructional technique is influenced by the content of training and learning principles identified [3]. Training should be aligned with the institutional or organisational strategic planning, while the training materials should be extracted from the professionals' experience arising from real work scenarios within organisations with the employees building on this content [56]. Training programs that are effective train for first the technical aspects of the industry; second basic literacy such as ability to read and write and computer literacy skills; and third interpersonal skills such as listening, good and clear communication, conflict management, problem solving and teamwork.

The right mix between basic and literacy skills and superior technical skills enabled the industrial take-off of Singapore and Malaysia. The take-off was preceded by an accumulation of literacy and basic skills, which were then supported by high-level technical skills [49]. Kenya could study how these economies have progressed and evaluate the possibility of replicating their training system.

Although TIVET graduates have superior basic skills compared to those without formal training, some exhibited low levels of computer skills because their institutions did not have well-equipped computer labs. [49] argue that the labour market needs to be knowledgeable in ICT to keep abreast with rapid technological changes, improve quality of work, maintain relevance, be flexible and offer life-long learning opportunities - attributes that are crucial for skilled labour. The level of theoretical knowledge exhibited by TIVET graduates have been acknowledged by employers as being satisfactory. The theory was not, however, matched by the practical know-how requisite at the workplace $[56,57$, 39]. The authors also observed that TIVET offers suitable interpersonal skills, sufficient competency in organisational, occupational health and safety, and basic accounting skills. Where academic instruction is not profession-based, findings show that students may excel in theory but fail in practical work [56]. This position influences employability of graduates because they do not meet the employer's expectation. In some cases graduates need retraining to fit into the industry [30].

Timing of implementation. At the national or macro level, determining the duration of a training program involves considering the amount of content so that it can be covered over the appropriate period of time without necessarily rushing or wasting students' time. [15] found that the duration of training has a big impact on the chances of employment, productivity and also on the degree of skill transfer from training institution to the workplace. For example, the above authors note that an additional 100 hours of the training period under observation achieves a higher level of proficiency, because learners who spend more time in training activities have assimilated more proficiencies and skills that afterwards enable them to gain entry into specific careers and to enhance performance in their occupations.

Resources required: Justifying a training decision requires a cost-benefit analysis of the projected results of the T\&D process, with the benefits expressed in quantifiable terms [4]. This is in recognition of the fact that in lean economic times, training programs are among the first activities to be forfeited. It is therefore vital to link the training activity with the expected results, such as productivity, quality or better service, in order to negotiate for financial support [59].

Expected rate of return: In different parts of the world, the objectives of $\mathrm{T} \& \mathrm{D}$ programs have shifted from a focus on program-based instruction (and behavioural and task analysis), to performance-system analysis, making learning a competitive approach at the workplace [12]. Numerous surveys, such as $[12,61]$ show that the production capacity of both employers and employees is expected to increase as a result of training. The paradox however, is that many employers shy away from developing their workers skills through training because they fear that by upgrading their skills, workers will become more marketable or become potential competitors [16].

\subsubsection{Training Objectives}

In the National TIVET Strategy, the Kenyan government has identified important areas that TIVET objectives are expected to address, such as: how many learners should take the course in a given year, how often the curriculum should be revised, and program funding. In addition, other extraneous factors, such as global dynamism, technological evolutions and developing 
trainers' teaching capacity, should be addressed in the training program [28]. This calls for more scientific identification of T\&D needs and expansion of TIVET's training objectives to encompass extraneous and other emerging needs.

The African Union (AU) report of 2007 recommends that VET national objectives in member countries be grouped into five specific areas that should be addressed by the syllabi: delivery of quality TIVET, graduates' employability, improvement of consistency and management by training providers, promotion of life-long learning, and enhancing the status and attraction of vocational education. These five areas were found to be most pertinent to TIVET in Kenya and were adopted as study areas for this paper. These five areas are discussed in more detail in the following section.

Delivery of quality TIVET: Skills acquisition, such as basic literacy and technical and interpersonal aptitudes, is one of the major focuses for a T\&D program. Skills are important for the workplace, but the ability to move away from being just taskfocused and skill-based to broader competencies is also essential, as skills that are acquired in the present may not suffice in the future [44, 62]. Formal education has a direct impact on the occupational success and upward mobility of individuals within the industry because, although education per se does not make one a successful worker, those with literacy and numeracy skills perform better than those without these skills [12, 62]. In West Africa, for example, some trainers prefer to take on trainees with a secondary school attainment because measuring, drawing and cutting are consequently easier for them to master $[1,63]$. To develop effective training programmes therefore, curriculum designers, researchers and training providers need to appreciate the interface between schooling and training [15].

While employers stress the importance of occupational skills they also demand other skills, which enable an employee to perform tasks efficiently, confidently, and to have positive relationships with the employer and other workers. Some of these skills were identified by [57] and are indicated in Figure 3 below.

\begin{tabular}{|c|c|c|}
\hline Occupational skills & Employable skills & $\begin{array}{l}\text { Interpersonal and } \\
\text { empowerment } \\
\text { skills }\end{array}$ \\
\hline $\begin{array}{l}\text { Using equipment safely } \\
\text { and effectively } \\
\text { - Selecting and using } \\
\text { materials and tools } \\
\text { - Reducing waste on costs } \\
\text { Observing quality } \\
\text { control instructions } \\
\text { - Increasing productivity } \\
\text { - Understanding drawings } \\
\text { and sketches }\end{array}$ & \begin{tabular}{|l} 
Language skills (oral \\
and written) \\
IT and computer \\
literacy \\
Communication skills \\
Influencing and \\
persuading others \\
Life-long learning \\
skills
\end{tabular} & $\begin{array}{l}\text { - Teamwork } \\
\text { - Flexibility and } \\
\text { adaptability } \\
\text { - Creativity and } \\
\text { innovation } \\
\text { - Problem-solving } \\
\text { and decision- } \\
\text { making } \\
\text { - Managing change }\end{array}$ \\
\hline
\end{tabular}

Source: UNDP (2010).

Figure 3. Category of skills.

At a national level, training providers need to recognise the role the internet has played in transforming the world into a global village. Thus, the perceived aim of VET institutions has moved from not only socialising learners into knowledge appreciated by the community, but also to enabling learners' participation in their own cultural transformation and adjusting to imminent changes that their societies will experience [44]. Consequently, education and training policymakers, curriculum designers, education providers and instructors increasingly need to develop curriculum, content and methods of instruction that are more relevant to the needs of the students and the industry at large. This could be done by simulating current workplaces, or through the use of computer databases and websites to process and manipulate training activities. Although this kind of project would require massive investments in equipment, in the long run it would enable trainees to access more diverse training. For instance, universities such as Kenyatta and Nairobi universities have invested in virtual labs, enabling their students to access learning from other parts of the world [28]. Graduates' employability: The development, employability and efficiency of the workers in organisations require current work-related competencies instead of the more general academic qualifications [60]. Further VET, focusing on human capital advances, job relatedness and performance outcomes, is stimulated by VET structures that depend on precise definition of economic environments [42]. The crucial issue is the relationship between training investment aimed at the development of human labour and an increase in social and economic development. Studies in training and employability show that VET increases the accessibility of skilled employment for job-market entrants [62].

Improvement of consistency and management by training providers: To develop a successful training policy, there is a need for governments to establish a skills inventory that identifies the national skills shortages through considering the available skills, the anticipated skill needs, current and future labour demands, technology, economic factors and the internal and external competition [59]. A well-articulated skills inventory will eliminate haphazard and unnecessary programmes, resulting in more productivity and better costbenefits for the country. When a country ignores technological advances, global trends and the aspirations of its people, a mismatch between the skills produced and the market demand will always persist [38, 55, 57].

Promotion of life-long learning: Life-long learning describes a continuous education inclination that is either formal or informal, and which engages people in multiple learning opportunities that are intentional, voluntary, and guided by a more learned person [5]. The continual scientific and technological inventions and global dynamics have had a great effect on training and learning needs and instruction styles over the years. Thus, some of today's learning does not need an institution, a specific learning style or a time-frame. In addition, acquired knowledge should not be confined to a specific workplace, but can be applied and developed for multiple workplaces.

Enhancing the status and attraction of VET: Introducing vocational education to the school system is an appropriate way of enhancing its status. However, the failure of VET to satisfy the needs of the industry is usually blamed on the quality and competency of teachers. Added to this is the view 
that vocational education is too involved, too broad and too time consuming to be taught during normal school hours.

In 2003 the Kenya government acknowledged that a majority of the instructors at the YPs had low academic levels and had not received training in pedagogy, despite their role in imparting skills [24] In addition the UNDP observed that whereas most of the trainers in TTI's and TI's had acquired professional teacher training positions, their qualifications were of a technical diploma level-yet they were expected to teach to the same level [57]. The KIE further added that the capacity of trainers to conduct research was too low to keep themselves abreast of new technologies [32].

\subsection{Training and Development Activities}

The assessment phase of an organisational T\&D model, serves as a foundation for the entire training program by analysing the training needs and specifying training objectives. The aim of this second phase-the activity phase - is to design a suitable environment to achieve the specified training objectives by carefully choosing methods and techniques and delivering the training systematically in a supportive and encouraging way [16].

From the reviewed literature and the examination of the organisational T\&D, this study identified for discussion five major areas that impact training activities in this section: training institutions (types, locations and the quality of their equipment); curriculum implementation (content and methods used in training); quality of trainers (their training and in-servicing); types of trainees (choices and quality of graduates); and socio-political factors.

Training institutions: To ensure their role is appreciated, and for their own competencies, training institutions need to establish a relationship with the industries so as to increase their understanding of the generic skills in the workplace and to include them in the preparation and delivery of the T\&D programs [19, 37]. This could be done by building the capacity of instructors through refresher courses, work experiences and workplace simulation.

Advocates of informal training of skills, argue that although a simulated workplace setting such as a training institution may be adequate to train the requisite skills, the process of "learning by doing" may yield similar, or even better, results if well carried out. Furthermore, [39] advanced that, notwithstanding the similarities in the learning and work environment, there is likely to be little transfer of learning from institution to the workplace. This is because the workplaces present changes in the context of modern technology that require more skills and innovation than the institutions train for. However, [59] acknowledges that prior knowledge acquired at the institution helps graduates to internalise the real job requirements needed to perform to the expected level of expertise.

Curriculum implementation: Once the type of training, the training institutions and training venues have been identified, the next step is curriculum implementation, which transforms the curriculum objectives and designs into skills needed to boost the industry through the transfer of skills and competencies from the trainers to the trainees. This involves the competent use of training methods (either formal or informal) based on sound learning principles. The aim is to furnish the trainees with the three types of skill necessary for an all-round worker: basic literacy, technical and interpersonal skills.

In a study to determine the factors that affect the employability of engineering students in technical institutions conducted by [65] it was found that the management of the curriculum, lecture interaction, contextual learning and infrastructure influence the employability of TIVET graduates. Other studies suggest that there is a higher likelihood of real learning during a training activity if the trainers increasingly make use of both their sensory and intellectual capabilities in the learning process instead of using a single faculty [59]. Thus, trainers should make use of activities that call for participants' proactive involvement in the learning process in group discussion, or individually, to enhance the learning process. In addition, linking theoretical learning with industrial experience acquiring work-based skills in entrepreneurship, problem solving, interpersonal skills and learning to work in the work-based context [46].

Trainees: For a successful implementation of a T\&D program, prospective trainees need to be identified carefully, as their input has the greatest impact on the program. In assessing the determinants of employment, [15] modelled the likelihood of accessing employment at diverse periods as a function of a prospective employee's personal traits - such as sex, age and academic level — and the quality of the training programme. The researchers found that the individual's age does not have a significant effect on the employment prospects in the first year, but after two years they found that the ratio of older people and that of younger people still employed was 3:5. The authors explained that older individuals are more likely to get jobs that are unstable, or they are able to live without employment for longer durations of time. Women were found to be more susceptible to unemployment after graduating, irrespective of the time-horizon considered.

T\&D designers have the duty of communicating industrial dynamics to their stakeholders and to look for ways of addressing the challenges, such as those identified above. This may involve revising the educational objectives and redesigning the training activities.

Trainers: The role of vocational trainers in curriculum implementation and delivery cannot be overemphasised. [19] advised that the instructors' capabilities, knowledge and expertise must be prudently scrutinised, stated and communicated for the importance of the trainers' role to be more appropriately acknowledged and understood in the vocation. In addition, [33] recommended that vocational teachers should adhere to established standards of teaching quality, develop competency records for their students during their program of study, and use technology tools to improve their instruction and, ultimately, the learning of the students.

In a study on learning transfer, [43] found that the factor with the highest mean rated by the respondents was trainer effectiveness. The factor consisted of five items: preparation, 
enthusiasm, commitment, relating the training content to the job needs and good feedback. Self-worth and work participation have a highly positive influence on effective training, and trainers that make use of methods that focus on the learners' sense of self-worth, while emphasising the occupational and professional benefits of training, have a higher success rate than those who don't make use of them [18].

In a national $T \& D$ program, the identification, recruitment and training of the VET trainers in pedagogy is vital to realising good outcomes. Imparting skills should not be left unregulated because poor work methods in trainers are likely to be replicated by the trainees, with disastrous results.

The UNDP indicated that YP trainers and MSE employers who also trained at the workplaces did not have pedagogy skills, which compromised the quality of the technical skills attained. To develop a national T\&D model this study viewed comprehensive examination of the contribution of VET trainers to job-related skills as a vital part of addressing skills demands of the MVRSI industry.

Socio-political factors: Studies on the impact of the training outcomes have suggested that the learners' social, economic and political backgrounds have a large influence on their training outcomes. [21] observed that "if the clientele of a training programme is highly disadvantaged or residing in an area of high unemployment, the impact of training will be less, hence poor employment of graduates may not necessarily mean that the training was of a poor quality" (p.187). On his part, [40] concluded that the heavy use of VET by learners from disadvantaged backgrounds in Australia raises concerns about social selection, and could lead to low self-esteem in trainees and low quality of skills. Further, the support offered to the trainees and the climate in which they learn is dictated by situational physiognomies such as declarative knowledge, learning incentives, acquisition of skills, reactions, transfer and job performance [18]. Thus political will is crucial in fostering TIVET goals and the philosophy of vocationalization [30]. In addition collaboration of labour officers curriculum planners, policy makers, lawmakers and education stakeholders is crucial. Literature gathered revealed that most TIVET institutions in Kenya are public, are managed by multiple ministries, are examined by multiple examination bodies, are located in the high economic potential areas of the country and are governed by boards that comprise political appointees. The issues and challenges require a political, as well as a social, solution. The reason being that it is generally acknowledged that education alone cannot deliver the many benefits associated with training-there is a need to create an enabling environment in other sectors of the economy to realise investments in education [34]. This study, therefore, deemed it fit to include socio-political factors that impact on TIVET as part of a more comprehensive study of the program, and the development of a national T\&D model.

\subsection{Training Evaluation}

There are three basic reasons for evaluating a training program: to find out how to improve the program, to determine the viability of the program, and to justify the existence of the training program to providers [36]. A sound evaluation system enquires into the feasibility of the training system and assesses the overall impact. [21] Observes that the results of the evaluation are vital in informing the public decision-making and stimulating debate, improving employer decisions about the training, informing the clients about training options and quality, and improving the quality of the training systems. The author adds that evaluation helps to avoid the possibility of wasting valuable resources by selecting optimum options, continuing with plans that are likely to produce intended results and detecting factors that may negatively impact on the training strategy. In this study, the Kirkpatrick's four levels of evaluation will guide the third part of the T\&D process - the evaluation phase.

The first phase is reactions level therefore measures the participants' interest, motivation, and attention levels [53]. This level is important for the future of the program because the motivations to learn, and changes in behaviour, are greatly influenced by the participants' positive reactions [36].

In the development of a T\&D model, reactions to TIVET were deemed important because it is the opinions and the impressions that the graduates voice that either encourage or discourage potential trainees. Furthermore, the motivation to learn is dependent upon how the trainees perceive the training program. The AU report of 2010 observed that VET in Africa is viewed as a pathway for those students who have low academic potential-making it an unattractive choice. Literature in Kenya TIVET has been gauged as inconsistent and inflexible and produces incongruent skills in comparison to the skill needs of the industry. This has led to a negative perception of the program because the public views it as wasteful in terms of resources and opportunities.

The second level is learning level seeks to obtain information on the extent to which learning objectives have been attained, knowledge acquired, skills developed or improved, and attitude changed to desired levels [4, 36]. Learning involves evaluating what the trainees have learned in terms of knowledge, skills and attitudes, which can be measured using written or practical assessments and roleplaying, with the aim of allowing learners to demonstrate their understanding of what has been learnt [53].

The third level of evaluation behaviour, measures the ability of the trainees to use their newly acquired knowledge or competencies at the workplace [65]. [36] observed that most organisations bypassed reactions and learning levels to measure behaviour. They noted that this was a serious mistake because failure to transfer skills and knowledge may be due to other exogenous factors of the training, which can be traced by measuring reactions and learning. Consequently, the authors identified four conditions necessary for changes in behaviour [36].

1) The person must have a desire to change.

2) The person must know what to do and how to do it.

3) The person must work in the right climate.

4) The person must be rewarded for changing.

In VET training, the level of technology in the institutions 
in comparison to that found in the industry has a big effect on the transfer of skills. [37] found that Australian VET graduates were more prepared for the workplace than their Kenyan counterparts due to the high level of sophisticated equipment found at the Australian training institutions compared to the Kenyan training facilities. Subsequently, the Kenyan graduates required more workplace training compared to those trained in Australian facilities.

Two dimensions to training performance and transferability were proposed by [40]: proceduralisation (ability to mimic modelled behaviour from the training to the job), and compilation (fluid performance with few errors after continued practice). Further, [8] identified three domains that affect the transfer of learned skills to the workplace:

1. trainee characteristics, which include individual elements such as ability, personality and motivation

2. training design, which refers to the relationship between the activities engaged in on the training program and the actual job requirements of the trainee and work environment

3. work environment, which is concerned with the degree to which the trainee has the opportunity to use and practice what has been imparted.

The fourth level is results, which measure the overall financial expenditure impact, production increase, reduced turnover and morale impacts $[36,52]$. In a formal training structure, results criteria in education include a wide variety of results, such as graduates' employment and increased workplace productivity, service to marginalised groups, social inclusion, improving literacy, personal and family economic stability, and responsible social conscience [50].

The three parts of a T\&D described in detail above, (i.e. T\&DNA, training activities and training evaluation) form the main parts of a national T\&D in Kenya. The expanded training model is represented diagrammatically in Figure 4 below, which represents the proposed model.

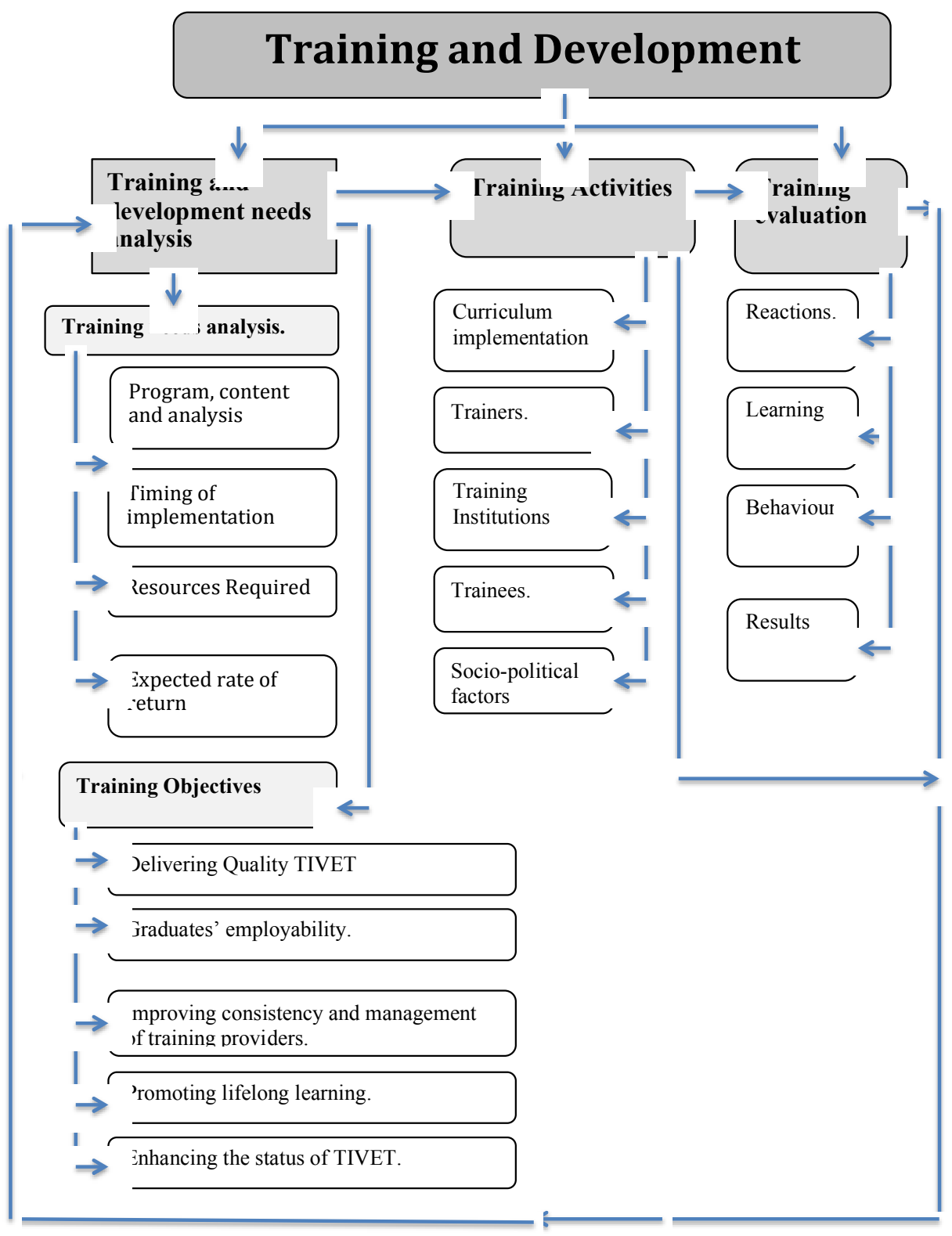

Figure 4. Proposed TIVET training and development model. 


\section{Conclusions}

To develop an effective T\&D program, the three phases of an organisational $T \& D$ are required. According to [59], an effective T\&D program develops an employee's productivity by comprehensively analysing training needs, engaging appropriate training activities, and proactively identifying factors beyond the training program that influence skills transfer from the institutions to the workplace. The author adds that a comprehensive TNA requires the use of multiple levels of stakeholders, such as front-line employees, grant administrators, supervisors, middle managers and executives. Moreover, there is a need to obtain the support and involvement of key stakeholders who have a direct interest in successful VET - such as the industry and the training providers; those who will use the analysed needs to decide what training will be offered, and the amount and type of resources required; and those who will directly benefit from acquisition of the skills [54].

Despite the importance of engaging stakeholders in a TNA, findings in this study revealed that in TIVET very few stakeholders take part in this process [37, 25, 49]. This research perused and analysed literature from different sources, which represented a wide range of stakeholders, views and assertions. This was important because the literature represent wide-ranging views from different perspectives, presenting insights into how different segments of society measure the same training, as proposed by different authors, such as [31].

This study suggests that the mismatch between the type and quality of skills that the TIVET institutions are producing and the skill needs of the industry is due to poor methods of carrying out a TNA. Critics argue that absent or inadequate TNA can result in incorrect and ineffectual training programs, which could either have a deleterious impact or no impact at all $[14,54,59])$. Therefore the need for an in-depth TNA that involves as many stakeholders as possible and uses diverse methods to collect and analyse data is invaluable, as demonstrated by this study. [2] argues that it is through having a clear base that a strong curriculum is built enabling training institutions to have a distinctive training identity instead of "being service providers whose "product" is redefined for each "client" (p. 640). In addition providing inadequate TNAs, African governments are too slow to adapt to global changes, and this is expounded by their T\&D structures which continue to practice adopted academic structures from their colonial masters, such as memorisation, passing of exams and certification without acquiring requisite skills to match the certificates [45]. While these methods may have been appropriate during the colonial times, they do not suffice today.

VET builds human capital that is vital to the development of any economy. Literature revealed that the degree to which TIVET is building this human capital is not sufficient to support a developing economy experiencing fast- changing global dynamics. An effective $T \& D$, which starts with the accurate assessment of training needs from multiple stakeholders, is vital to discern the gaps that may exist in the training program. Once the gaps have been identified, the training activities are then examined to find out how the needs can be addressed through training designs, and the methodologies are then chosen $[55,59]$. The last phase of an organisational T\&D program involves evaluating the program by examining its outcomes against the set goals [36]. The results of the evaluation are then used to carry out more TNAs. This is a cyclical process that involves the three mentioned phases of a $T \& D$ program, and a gap in any of these phases can result in a deficiency in skills.

The organisational T\&D model is used as a guide for developing and designing effective training programs in organisations. However, it was found that to suit a national program, the T\&D model needed to be modified by specifying composite parts. Thus, this study reviewed literature from the Kenyan education system, an organisational T\&D model from different authors. The organisational T\&D model was then expanded and customised to the needs of the Kenyan TIVET context and then a model was developed for this study.

\section{Implications for T\&D Research}

This study extends the body of knowledge on T\&D, and builds on earlier work for example [13, 15] who researched on the contribution of VET to skills development; [14, 29, 17] who researched TNA processes; and, [21, 36, 52] who contributed significantly in the field of training evaluations. By building on the work of these researchers and developing a proposed T\&D model for a developing country, this study aims to open debate on processes that can either add value or transform the T\&D programs that already exist in countries that are similar to Kenya. Furthermore, this study established that there is a dearth in the amount of literature that is dedicated to T\&D programs in developing countries especially those in Africa. It is hoped that other researchers in Africa and elsewhere can critique, add or adopt the model developed in this study to improve $\mathrm{T} \& \mathrm{D}$ programs for the MSEs, and even large enterprises in different countries.

\section{Areas for Future Research}

This research focussed only on Kenya. Future research can be based on a comparative study of VET in Kenya and other developing countries that have different processes of training. For example, this study found that Gabon, in West Africa, has a VET participation rate of 12.7 per cent while that of Kenya is less than 2 per cent [1] and yet South Africa is more economically developed. 


\section{References}

[1] Afeti, G. (2009). Technical and vocational education and training for industrialization. Retrieved October, 4, 2011.

[2] Allais, S. Will skills save us? Rethinking the relationships between vocational education, skills development policies, and social policy in South Africa. International Journal of Educational Development, 32 (5), (2012). 632-642.

[3] Alvarez, K., Garofano, C., \& Salas, E. An integrated model of training evaluation and effectiveness. Human Resource Development Review, 3 (4), (2009). 385-416.

[4] Armstrong, M. Armstrongs handbook of human resource management practice (2009). (11th ed.). London: Kogan Page Limited.

[5] Arrington, T. L., \& Lowe, P. A. "Life-long Learning." Encyclopedia of Educational Psychology. Ed. (2008). (Vol. 606-09). Thousand Oaks, CA: SAGE.

[6] Atchoerena, D. D. A. Revisiting Technical and Vocational Education in Sub-Saharan Africa: an update on trends innovations and challenges. (2001). International Institute for Educational Planning: Paris.

[7] African Union [AU]. Strategy to revitalize technical and vocational education and training (TVET) in Africa. In Meeting of the Bureau of the Conference of Ministers of Education of the African Union (COMEDAF II+) (2009, May). 29-31.

[8] Baldwin, T. T., \& Ford, J. K. (1988). Transfer of training: a review and directions for future research. Personnel Psychology 41, 63-105.

[9] Barasa, F. S., \& Kaabwe, E. S. Fallacies in policy and strategies of skills training for the informal sector: evidence of the Jua Kali sector in Kenya. Journal of Education and Work., 14 (3), (2001). 329-353.

[10] Beardwell, J., \& Claydon, T. Human Resource Management: A Contemporary Approach (5 $5^{\text {th }}$ ed.). (2009). London: Pearson Education Limited.

[11] Bennell, P. The Impact of Economic Liberalisation on Private Sector Training Provision in Zimbabwe. Assessment in Education: Principles, Policy \& Practice, 7 (3), (2000). 439454.

[12] Berge, Z., Verneil, M., Berge, N., Davis, L., \& Smith, D. The increasing scope of training and development competency. Benchmarking: An International Journal, 9 (1) (2002)., 43-61.

[13] Brockmann, M., Clarke, L., Méhaut, P., \& Winch, C. Competence-based vocational education and training (VET): The cases of England and France in a European perspective. Vocations and Learning, 1 (3), (2008). 227-244. doi: 10.1007/s12186-008-9013-2.

[14] Brown, J. Training needs assessment: A must for developing an efficient training programme. Public, Personnel Management, 31 (4), (2002). 569-578.

[15] Budría, S., \& Telhado-Pereira, P. The contribution of vocational training to employment, job-related skills and productivity: evidence from Madeira. International Journal of Training and Development, 13 (1), (2009). 53-72.
[16] Cascio, W. Managing human resources: productivity, quality of work life, profits (8th ed.). (2010). New York: McGrawHill/Irwi.

[17] Cekada, T., LTraining needs assessment. Professional Safety, 55 (3), (2010). 28.

[18] Colquitt, J. A., LePine, J. A., \& Noe, R. A. Toward an integrative theory of training motivation: a meta-analytic path analysis of 20 years of research: A Meta-Analytic Path Analysis of 20 Years of Research. The Journal of Applied Psychology, 85 (5), (2000). 678-707.

[19] Dalton, J., \& Smith, P. (2004). Vocational education and training in secondary schools: challenging teachers' work and identity. Journal of Vocational Education and Training, 56 (4), 507.

[20] Fluitman, F. The roots and nature of reforms in vocational education and training: An analytical framework and some examples. Prospects, 29 (1), (1999). 55-65.

[21] Fretwell, D. A framework for evaluating vocational education and training (VET). European Journal of Education, 38 (2), (2003). 177-190.

[22] Government of Kenya [GoK]. National MSE baseline survey. Nairobi: (1999). Government Printer.

[23] Government of Kenya [GoK]. Economic recovery strategy for wealth and employment creation 2003-2007. Nairobi: (2003a). Government Printer.

[24] Government of Kenya [GoK]. A rapid appraisal on the status of technical and vocational education and training (TIVET) in Kenya. (2003b). Nairobi. Government Printer.

[25] Government of Kenya [GoK]. Kenya Vision 2030. (2007). Nairobi: Government Printer.

[26] Government of Kenya [GoK]. The NationalTechnical, industrial, vocational and entrepreneurship training (TIVET) strategy. Nairobi: Government Printer.

[27] Government of Kenya [GoK]. The development of education: National report of Kenya. Nairobi: (2008b). Government Printer.

[28] Government of Kenya [GoK]. MoHEST strategic plan 20082012. Nairobi: (2008c). Govrnment Printer.

[29] Hauer, J., \& Quill, T. Educational needs assessment, development of learning objectives, and choosing a teaching approach. Journal of Palliative Medicine, 14 (4), (2011). 53508 .

[30] Jane Itohan Oviawe, Raymond Uwameiye, Patrick S. O. Uddin. Bridging Skill Gap to Meet Technical, Vocational Education and Training School-Workplace Collaboration in the 21s Century. International Journal of Vocational Education and Training Research. Vol. 3, No. 1, 2017, pp. 7-14. doi: 10.11648/j.ijvetr.20170301.12.

[31] Kagaari, J. Evaluation of the effects of vocational choice and practical training on students' employability Journal of European Industrial Training, 31 (6), (2007). 449.

[32] Kenya Institute of Education [KIE].). Strategic plan 20062007. Nairobi: (2006 Ministry of Education. 
[33] Khasawneh, S., A, Olimat, M., Qablan, A., \& Abu-Tineh, M. Measuring the perceptions of vocational education students regarding the application of national vocational teacher standards in the University Classrooms: The key to human resource education in Jordan. International Journal of Applied Educational Studies, 2 (1), (2008). 24.

[34] King, K. Balancing basic and post-basic education in Kenya: National versus international policy agendas. International Journal of Educational Development, 27 (4), (2007) 358-370.

[35] Kinyanjui, M. N. Jua Kali Strategies for Socio-Economic Change in Nairobi. Hemispheres (26), (2011). 29-47.

[36] Kirkpatrick, D., \& Kirkpatrick, JEvaluating training programs. (2005). (3rd ed.). San Francisco, CA: BerretKoehler Publishers.

[37] Kitainge, K.). Voices of the stakeholders: A case of power mechanics in Kenya. International Journal of Training Research, 1 (2), (2009). 21-39.

[38] Kitainge, K. Is institution based training for the future in the automotive industry?: what the trainees have to say. (2004). Paper presented at the Australian Vocational Education and Training Research Association (AVETRA).

[39] Kitainge, K. Challenges of training motor vehicle mechanics for changing world contexts and emergent working conditions: Cases of Kenya and Australia. Handbook of Research on E-Learning Applications for Career and Technical Education: Technologies for Vocational Training, 1, (2009). 34-46.

[40] Kraiger, K. (2002). Decision-based evaluation. In K. Kraiger (Ed.), Creating, implementing, and managing effective training and development (pp. 331-375). San Francisco, CA: Jossey-Bass.

[41] Masson, J., \& Fretwell, D. The European Union: Supporting technical and vocational education. Techniques, 84 (7), (2009). 48-51.

[42] Mccoshan, A. Beyond the Maastricht communiqué: developments in the opening up of VET pathways and the role of VET in labour market integration. (2008). Birmingham: Priestley House.

[43] McGrath, S. Where to now for vocational education and training in Africa? International Journal of Training Research, 9 (1-2), (2011). 35-48.

[44] Munro, J. Fostering internationally referenced vocational knowledge: A challenge for international curricula. Journal of Research in International Education, 6 (1), (2007). 67-93.

[45] Ngoa-Nguele, D., \& Stolovitch, H. D. Structured on-the-job training in developing nations. Advances in Developing Human Resources, 3 (4), (2001). 461-470.

[46] National Research Center for Career and Technical Education, Work-based learning opportunities for high school students, 2013. Retrieved from http://www.nrccte.org/.

[47] Ngerechi, J. B. Technical and vocational education in Kenya. (2003). Paper presented at the Conference on the Reform of Technical And Vocational Education and Training (TVET) Gaborone, Botswana.

[48] Nyerere, J. X Technical, industrial \& vocational education and training (TIVET) sector mapping in Kenya. Nairobi: (2009).
Dutch Schokland TVET programme.

[49] Onsomu, E., Wambugu, a., Wamalwa, F. Improving technical and vocational training in Kenya: Lessons from selected countries. In S. S. Division (Ed) KIPPRA Discussion Paper No. 105 (2009) (pp 53-56). Nairobi: Kenya Institute for Public Policy Research and Analysi [KIPPRA].

[50] Praslova, L. Adaptation of Kirkpatrick's four level model of training criteria to assessment of learning outcomes and program evaluation in Higher Education. Educational Assessment, Evaluation and Accountability, 22 (3), (2010). 215-225. doi: 10.1007/s11092-010-9098-7.

[51] Ridha, A.-K. Training and development needs assessment: a practical model for partner institutes. Journal of European Industrial Training, 22 (1), (1998). 18-27.

[52] Rodgers, Y., \& Boyer, T. Gender and racial differences in vocational education: an international perspective. International Journal of Manpower, 27 (4), (2006). 308-320.

[53] Smidt, A., Balandin, S., Sigafoos, J., \& Reed, V. A. The Kirkpatrick model: A useful tool for evaluating training outcomes. Journal of Intellectual \& Developmental Disability, 34 (3), (2009). 266-266..

[54] Sonobe, T., Akoten, J., \& Otsuka, K. The growth process of informal enterprises in Sub-Saharan Africa: a case study of a metalworking cluster in Nairobi. Small Business Economics, 36, (2011). 323-335.

[55] Stone, J. Managing human resources (2010). (3 ed.): John Wiley \&Sons Australia, Ltd.

[56] Seyedeh Armaghan Azhar, Mohammad Amin Zandi, The Gap Between Educational System and Job Market in International Business Law: A Model of Specialization for Solving the Problem, International Journal of Vocational Education and Training Research. Vol. 3, No. 6, 2017, pp. 51-60. doi: 10.11648/j.ijvetr.20170306.11.

[57] UNDP. (2010). Skills gap analysis for graduates of youth polytechnics, vocational training centres and out of school youths. Nairobi: Government Of Kenya.

[58] Wachira, N., Root, D., Bowen, P. A., \& Olima, W. An investigation into informal craft skilling in the Kenyan and South African construction sectors. In $5^{\text {th }}$ post graduate conference on construction industry development (2006). (p. 300-341).

[59] Wagonhurst, C. Developing effective training programs. Journal of Research Administration, 33 (2), (2002). 77-81.

[60] Walker, E., \& Redmond, J. (2008). A new approach to small business training: community based education. Education and Training, 50 (8/9), 697-712.

[61] Wallenborn, M. Vocational Education and Training and Human Capital Development: current practice and future options. European Journal of Education, 45 (2), (2010). 181198.

[62] Wheelahan, L., \& Carter, R. National training packages: a new curriculum framework for vocational education and training in Australia. Education and Training, 43 (6), ( 2001). 73-96.

[63] Williams, C. R. Skills formation in the Kenya informal sector (1980). Working Paper No. 362. Nairobi: Institute for Development Studies. 
[64] Yun-Tsan, L., Shui-Chuan, C., \& Hsiang-Ta, C. The effect of organizational commitment on employee reactions to educational training: An evaluation using the Kirkpatrick fourlevel model. International Journal of Management, 28 (3), (2011). 926-931.

[65] Yusof, H., Ramlee, M., Syed A. Malik, Mohammad Sattar, R., dan Seri Bunian, M. Employability skills, co-curriculum, peer interaction, contextual learning: International Technical HRD \& 9th ASIAN Academic Society For Vocational Education and Training Conference 2013 (AASVET Conference 2013). Kuching: Sarawak Skills Development Centre (SSDC). Kuantan: University Teknologi MARA.

[66] Ziderman, A. Financing vocational training in sub-Saharan Africa. (2003). Washington: World Bank Publications. 